\title{
On the Mechanism of Magnesium Storage in Micro- and Nano-Particulate Tin Battery Electrodes
}

\author{
Francisco Nacimiento, Marta Cabello, Carlos Pérez-Vicente, Ricardo Alcántara ${ }^{\circledR}$, Pedro Lavela ${ }^{(0)}$, \\ Gregorio F. Ortiz * (iD) and José L. Tirado (i) \\ Departamento de Química Inorgánica e Ingeniería Química, Instituto Universitario de Investigación en Química \\ Fina y Nanoquímica IUIQFN, Universidad de Córdoba, Campus de Rabanales, Edificio Marie Curie, \\ E-14071 Córdoba, Spain; q92nacof@uco.es (F.N.); z22cabbm@uco.es (M.C.); iq3pevic@uco.es (C.P.-V.); \\ iq2alror@uco.es (R.A.); iq1lacap@uco.es (P.L.); iq1ticoj@uco.es (J.L.T.) \\ * Correspondence: q72maorg@uco.es; Tel.: +34-957-218637
}

Received: 8 June 2018; Accepted: 4 July 2018; Published: 6 July 2018

\begin{abstract}
This study reports on the electrochemical alloying-dealloying properties of $\mathrm{Mg}_{2} \mathrm{Sn}$ intermetallic compounds. ${ }^{119} \mathrm{Sn}$ Mössbauer spectra of $\beta$-Sn powder, thermally alloyed cubic- $\mathrm{Mg}_{2} \mathrm{Sn}$, and an intermediate MgSn nominal composition are used as references. The discharge of a $\mathrm{Mg} /$ micro-Sn half-cell led to significant changes in the spectra line shape, which is explained by a multiphase mechanism involving the coexistence of c- $\mathrm{Mg}_{2} \mathrm{Sn}$, distorted $\mathrm{Mg}_{2-\delta} \mathrm{Sn}$, and $\mathrm{Mg}$-doped $\beta$-Sn. Capacities and capacity retention were improved by using nanoparticulate tin electrodes. This material reduces significantly the diffusion lengths for magnesium and contains surface $\mathrm{SnO}$ and $\mathrm{SnO}_{2}$, which are partially electroactive. The half-cell potentials were suitable to be combined versus the $\mathrm{MgMn}_{2} \mathrm{O}_{4}$ cathodes. Energy density and cycling properties of the resulting full $\mathrm{Mg}$-ion cells are also scrutinized.
\end{abstract}

Keywords: electrode nanomaterials; magnesium-tin intermetallics; magnesium-ion batteries; Sn-119 Mössbauer spectroscopy

\section{Introduction}

Recent concerns regarding the future availability of lithium (Li) [1-4], together with safety issues [5] affecting Li-ion batteries have prompted expanding research activity on alternatives to lithium. Due to its high abundance, easy extraction and moderate cost, magnesium $(\mathrm{Mg})$ is one of the multivalent elements that show promising possibilities [6-13]. Despite its lower potential compared with lithium, Mg electrodes provide higher volumetric capacity and shows a better reconstruction of its surface on cycling, being less prone to form dendrites on electroplating. $\mathrm{Mg}^{2+}$ ions have a similar radius to $\mathrm{Li}^{+}$ones and avoid pronounced volume changes on cycling. However, there is a major difficulty in obtaining reliable $\mathrm{Mg}$-anode batteries, related with the stability of electrolyte solutions $[12,13]$. Thus, electrolytes commonly stable versus $\mathrm{Mg}$ are mostly unstable versus common cathodes found so far and vice versa. For this reason, the research for alternative anodes and hence the concept of $\mathrm{Mg}$-ion batteries is also valid for this alkali-earth element. Recently, the chemical and electrochemical $\mathrm{Mg}$ deinsertion from $\mathrm{MgMn}_{2} \mathrm{O}_{4}$, which leads to $\mathrm{Mg}_{1-x} \mathrm{Mn}_{2} \mathrm{O}_{4}$ or $\lambda-\mathrm{MnO}_{2}$, has been reported using both aqueous and non-aqueous electrolytes [14-16]. While examining the possible use of several materials as anodes to be combined vs. $\mathrm{MgMn}_{2} \mathrm{O}_{4}$ as a positive electrode, the most successful results were found for tin $(\mathrm{Sn})$, a material previously reported to have reversible electrochemical alloying reactions with $\mathrm{Mg}$ [17]. To study these alloying reactions, we apply ${ }^{119} \mathrm{Sn}$ Mossbauer spectroscopy (MS), a uniquely selective technique, to study changes in the oxidation state and chemical environment of tin. When tin oxides and intermetallic compounds are used as active electrode material in lithium 
batteries, ${ }^{119}$ Sn MS provides valuable information [18-22]. Particularly, Aldon et al. found ${ }^{119}$ Sn MS useful to study lithium insertion in c- $\mathrm{Mg}_{2} \mathrm{Sn}$ [21].

$\mathrm{A}^{119} \mathrm{Sn}$ Mössbauer study is reported here for Sn powdered electrodes in $\mathrm{Mg}$ test cells, to unveil the details of the complex mechanism of the electrochemical reaction, which involves a tin-rich intermetallic phase with an electric field gradient environment of tin atoms and cubic $\mathrm{Mg}_{2} \mathrm{Sn}$. Also, due to the increasing interest in nanomaterials for battery applications [23,24], the optimization of the electrode was carried out by using a nano-dispersed $\mathrm{Sn}-\mathrm{SnO}_{x}$ composite powder that provides a unique surface electroactive coating of tin oxides, allowing for better cycling stabilities. Finally, the nano-tin electrodes are combined with a low temperature $\mathrm{MgMn}_{2} \mathrm{O}_{4}$ material recently reported by our research group to obtain a novel suitable Mg-ion battery.

\section{Materials and Methods}

Commercial magnesium strip (purity $\geq 99 \%$, Sigma-Aldrich Química S.L., Madrid, Spain) and micro- and nano-Sn (Aldrich) powders were used as received. Thermally prepared Mg-Sn intermetallic samples included stoichiometric crystalline $\mathrm{Mg}_{2} \mathrm{Sn}$ and a sample with $\mathrm{MgSn}$ nominal stoichiometry. Both thermal samples were obtained from mechanical mixtures of $\mathrm{Mg}$ and micro-Sn, which were heated at $700{ }^{\circ} \mathrm{C}$ for $1 \mathrm{~h}$ and then cooled to room temperature at $4{ }^{\circ} \mathrm{C} \min ^{-1}$ in a $\mathrm{N}_{2}$ atmosphere. The low-temperature spinel (LT)- $\mathrm{MgMn}_{2} \mathrm{O}_{4}$ was prepared as described elsewhere [16], following the Pechini method. The dry powdered precursor was first heated at $200{ }^{\circ} \mathrm{C}$, ground in an agate mortar and then heated at $400{ }^{\circ} \mathrm{C}$ for ten hours.

The electrochemical experiments were performed in a multichannel VMP instrument (Bio-Logic, Barcelona, Spain). Swagelok-type cells were mounted in an M-Braun glove-box filled with Ar. Tin powders and magnesium strips were used as received. The working electrodes were a mixture of active material:carbon black:polyvinylidene difluoride (PVDF) binder in a 80:10:10 ratio supported on Ti substrate. The carbon black additive was supplied by Société des Accumulateurs Fixes et de Traction (S.A.F.T., Bordeaux, France). The electrode mass load was $3.0-5.0 \mathrm{mg} \mathrm{cm}^{-2}$. Several non-aqueous electrolyte solutions were tested, including $0.5 \mathrm{M} \mathrm{PhMgCl}$ in tetrahydrofuran (THF) or $0.5 \mathrm{M} \mathrm{EtMgCl}$ in THF for $\mathrm{Mg} / \mathrm{Sn}$ half cells, and $0.5 \mathrm{M} \mathrm{Mg}\left(\mathrm{ClO}_{4}\right)_{2}$ in acetonitrile (AN) for full cells. Mg-ion full cells were tested in Swagelok ${ }^{\mathrm{TM}}$-type three-electrode cells to monitor separately cathode and anode voltages versus a reference electrode consisting of a metallic Mg disk.

X-ray diffraction (XRD) measurements were carried out in a Bruker D8-Advance instrument (Bruker Española S.A., Madrid, Spain) with $\mathrm{CuK}_{\alpha 1}$ radiation. Ex-situ XRD patterns of discharged electrodes were recorded by dismantling the electrochemical cells in the dry box under Ar atmosphere and, after recovering the electrodes and separating them from the Ti collector, covering them with a Kapton bag to avoid contact with air.

The ${ }^{119} \mathrm{Sn}$ Mössbauer spectra (MS) were recorded in a WissEl instrument (WissEl-Wissenschaftliche Elektronik $\mathrm{GmbH}$, Starnberg, Germany) at room temperature. The spectra were recorded with adequate acquisition time to permit a deconvolution, typically ten days. The ${ }^{119} \mathrm{Sn}$ isomer shifts are referenced to $\mathrm{BaSnO}_{3}$. A pure $\beta$-Sn foil was used for the calibration. For the fitting of the experimental spectra, the WINSO1.0 program (F. Landry, P. Schaaf, WinISO: Windows Mössbauer Fitting Program, unpublished), Lorentzian line-shape absorption peaks, and a least-squares method were employed. When the fitting process reached the convergence, the quality of the fitting was controlled by the classical $\chi^{2}$-test. The Mössbauer spectra of discharged electrodes were recorded ex-situ by putting the active material under Ar atmosphere in polybags (Aldrich), which were hermetically closed by heat-sealing with a commercial heat sealer at $150{ }^{\circ} \mathrm{C}$.

Field-Emission Scanning Electron Microscope (FESEM) images were obtained in JEOL FESEM (Izasa Scientific, Madrid, Spain) 1400 provided with Energy-dispersive X-ray spectroscopy (EDX). 


\section{Results}

Figure 1 shows the X-ray diffraction patterns of thermally prepared, crystalline cubic c- $\mathrm{Mg}_{2} \mathrm{Sn}$, a fluorite-type structure, and the thermally prepared $\mathrm{MgSn}$ material, which contains both crystalline $\beta-\mathrm{Sn}$ and $\mathrm{c}-\mathrm{Mg}_{2} \mathrm{Sn}$ with visible traces of $\mathrm{MgO}$ impurities and unreacted $\mathrm{Mg}$.

Figure 2a shows the ${ }^{119} \mathrm{Sn}$ MS data for the commercial tin microparticles. The observed isomer shift (IS) value of $2.561_{9} \mathrm{~mm} \mathrm{~s}^{-1}$ (Table 1) and its negligible quadrupolar splitting are consistent with a high-purity and well crystallized $\beta$-Sn phase.

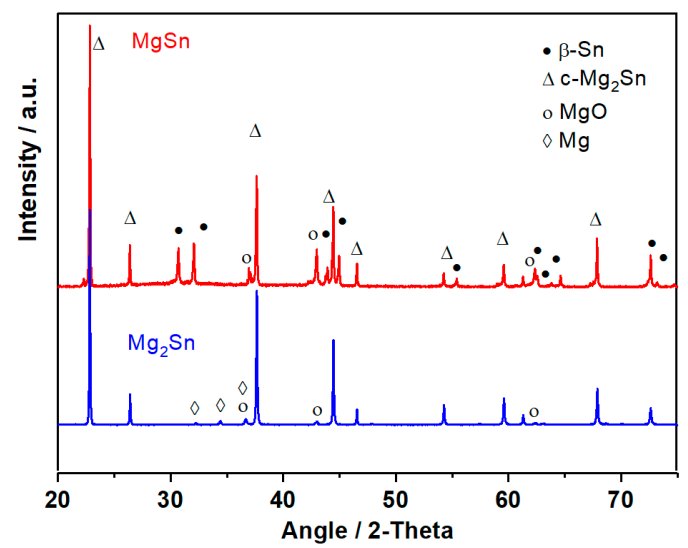

Figure 1. Powder X-ray diffraction (XRD) patterns of the thermally prepared samples with $\mathrm{Mg}_{2} \mathrm{Sn}$ and MgSn nominal compositions.

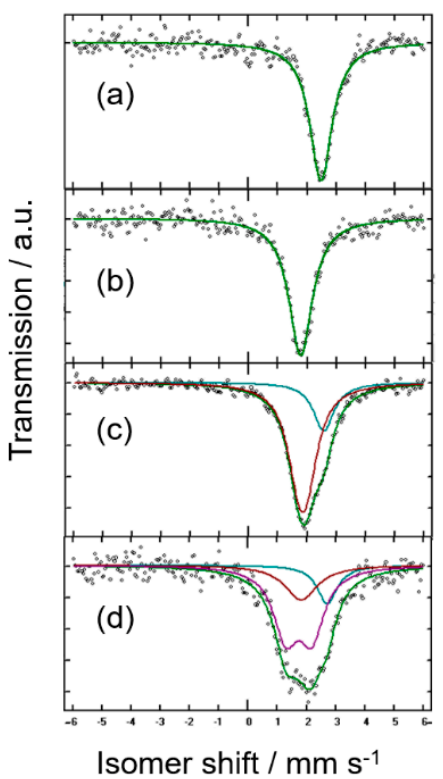

Figure 2. ${ }^{119} \mathrm{Sn}$ Mössbauer spectra of (a) tin microparticles, and thermally prepared samples with (b) $\mathrm{Mg}_{2} \mathrm{Sn}$ and (c) MgSn nominal compositions. (d) micro-Sn electrode after discharge in $\mathrm{Mg}$ half-cell to a $\mathrm{Mg}_{0.4} \mathrm{Sn}$ nominal composition.

Figure $2 \mathrm{~b}$ shows the spectrum of the crystalline $\mathrm{Mg}_{2} \mathrm{Sn}$ alloy. The IS value of $1.847_{9} \mathrm{~mm} \mathrm{~s}^{-1}$ is ascribable to cubic c- $\mathrm{Mg}_{2} \mathrm{Sn}[21,25]$. In agreement with the well-known fluorite-type structure of $\mathrm{c}-\mathrm{Mg}_{2} \mathrm{Sn}$, tin atoms are eight-fold coordinated by magnesium and twelve-fold coordinated by tin second neighbors, which is in contrast with the use of less and more directional covalent bonds in $\beta$-Sn and agrees with the significantly lower isomer shift relative to $\beta$-Sn (Figure 2a). Again, the highly symmetric coordination of tin atoms in the structure impedes a quadrupole splitting of the signal 
(Table 1). The spectrum of thermal MgSn shows two deconvoluted contributions close to c- $\mathrm{Mg}_{2} \mathrm{Sn}$ and $\beta$-Sn-related phases (Figure $2 c$ ). However, this spectrum reveals unexpected results. Thus, the singlets ascribable to crystalline $\beta-\mathrm{Sn}$ and $\mathrm{c}-\mathrm{Mg}_{2} \mathrm{Sn}$ were not sufficient to fit the spectrum. A significant quadrupole splitting $\left(0.30_{4} \mathrm{~mm} \mathrm{~s}^{-1}\right)$ of the low IS signal was also present (Table 1$)$. This visually unresolved doublet is indicative of the presence of tin nuclei in a low symmetry environment of $\mathrm{Sn}$ atoms. It is probably due to incomplete coordination by $\mathrm{Mg}$ atoms, in a metastable, non-stoichiometric and distorted $\mathrm{d}-\mathrm{Mg}_{\delta} \mathrm{Sn}$ phase, which is not discerned from the crystalline products in the XRD patterns. This result is consistent with the report by Sirkin et al. [26] on quenched ternary Sn-Mg-M alloys, and latter corroborated by theoretical calculations by Fries and Lukas [27].

Table 1. Isomer shift (IS), quadrupolar splitting (QS), line width (LW), \% contribution and attribution of the signals appearing in the ${ }^{119} \mathrm{Sn}$ Mössbauer spectra of commercial micro- and nano-Sn, mechanochemically produced $\mathrm{Mg}_{2} \mathrm{Sn}$. and discharged/recharged electrodes. * Recoilless fractions, $f=0.05$ (Sn). Reproduced with permission of [28,29]. Copyright Elsevier, 2000, 1966. $f=0.3$ (c- $\left.\mathrm{Mg}_{2} \mathrm{Sn}\right)$ Reproduced with permission of [29]. Copyright Elsevier, 1966. $f=0.15\left(\mathrm{Mg}_{2-\delta} \mathrm{Sn}\right.$; ca. half of the reported value [29], due to the possible tin excess). These values were used to convert spectral contributions (\%) into semiquantitative composition (\% $\left.\%_{\text {corr }}\right)$.

\begin{tabular}{|c|c|c|c|c|c|c|}
\hline Sample (Nominal) & $\mathrm{IS} / \mathrm{mms}^{-1}$ & $\mathrm{QS} / \mathrm{mms}^{-1}$ & $\mathrm{LW} / \mathrm{mms}^{-1}$ & $\%$ & $\%_{\text {corr }}{ }^{*}$ & Attribution \\
\hline (a) micro-Sn & $2.561_{9}$ & - & $0.95_{3}$ & 100 & 100 & $\beta-S n$ \\
\hline (b) thermal- $\mathrm{Mg}_{2} \mathrm{Sn}$ & $1.847_{9}$ & - & $0.99_{3}$ & 100 & 100 & $\mathrm{c}-\mathrm{Mg}_{2} \mathrm{Sn}$ \\
\hline \multirow[t]{2}{*}{ (c) thermal-MgSn } & $2.64_{3}$ & - & $0.87_{7}$ & 24 & 49 & $\beta-S n$ \\
\hline & $1.91_{3}$ & $0.30_{4}$ & $0.96_{4}$ & 76 & 51 & $\mathrm{Mg}_{2-\delta} \mathrm{Sn}$ \\
\hline (d) micro- $\mathrm{Mg}_{0.4} \mathrm{Sn}$ & $2.79_{8}$ & - & $1.83_{1}$ & 15 & 38 & $\beta-S n$ \\
\hline \multirow[t]{2}{*}{ discharged } & $1.8_{2}$ & - & $1.4_{5}$ & 21 & 9 & $\mathrm{c}-\mathrm{Mg}_{2} \mathrm{Sn}$ \\
\hline & $1.79_{5}$ & $0.908_{2}$ & $1.051_{2}$ & 64 & 53 & $\mathrm{Mg}_{2-\delta} \mathrm{Sn}$ \\
\hline
\end{tabular}

Figure 3a,b shows the cycling properties of the $\mathrm{Mg} / 0.5 \mathrm{M} \mathrm{PhMgCl}$ (THF)/micro-Sn cell. Extremely low capacity values were obtained in the 0.01-0.6 V potential window, although the capacity increases upon cycling $\left(<10 \mathrm{~mA} \mathrm{~h} \mathrm{~g}^{-1}\right)$, probably indicating the progressive conditioning of the metal electrode surface. According to the Gibbs phase rule, the presence of well-defined plateaus in both discharge and charge should be consistent with a biphasic mechanism of the alloying-dealloying reaction:

$$
\beta-\mathrm{Sn}+2 \mathrm{Mg}^{2+}+4 \mathrm{e}^{-} \rightleftharpoons \mathrm{c}-\mathrm{Mg}_{2} \mathrm{Sn} \text { (Theoretical capacity } 903 \mathrm{~mA} \mathrm{~h} \mathrm{~g}(\mathrm{Sn})^{-1} \text { ) }
$$

The reaction mechanism of the micro-Sn electrodes was explored by using ${ }^{119}$ Sn MS. Figure $2 \mathrm{~d}$ shows the results for a discharged electrode prepared by applying multiple galvanostatic pulses followed by relaxation periods to a $\mathrm{Mg} /$ micro-Sn half-cell until a stable nominal $\mathrm{Mg}_{0.4} \mathrm{Sn}$ stoichiometry was achieved. The spectrum shows significant changes in line shape as referred to the pristine tin microparticles (see Figure 2a) that agree with tin electroactivity. The IS parameters shown in Table 1 evidence the simultaneous presence of a $\mathrm{Mg}$-deficient, distorted $\mathrm{Mg}_{2-\delta} \mathrm{Sn}$ phase, a $\beta$-Sn-related phase with possible $\mathrm{Mg}$ doping and c- $\mathrm{Mg}_{2} \mathrm{Sn}$, which partially agrees with the biphasic mechanism suggested above. The low proportion of $\mathrm{c}-\mathrm{Mg}_{2} \mathrm{Sn}$ is indicative of impediments to the full conversion of the tin microparticles, probably due to an incomplete diffusion of magnesium through the larger tin particles. Moreover, the high broadening and significant quadrupole splitting of the $\mathrm{d}-\mathrm{Mg}_{\delta} \mathrm{Sn}$ signal may point to a structural deterioration and/or partial $\mathrm{Mg}$ alloying in a metastable phase yielding many different local environments of the tin atoms. It is well known that electrochemical reactions may lead to metastable products, thus being one of the most useful soft-chemistry synthetic routes for the solid state [18-22]. 

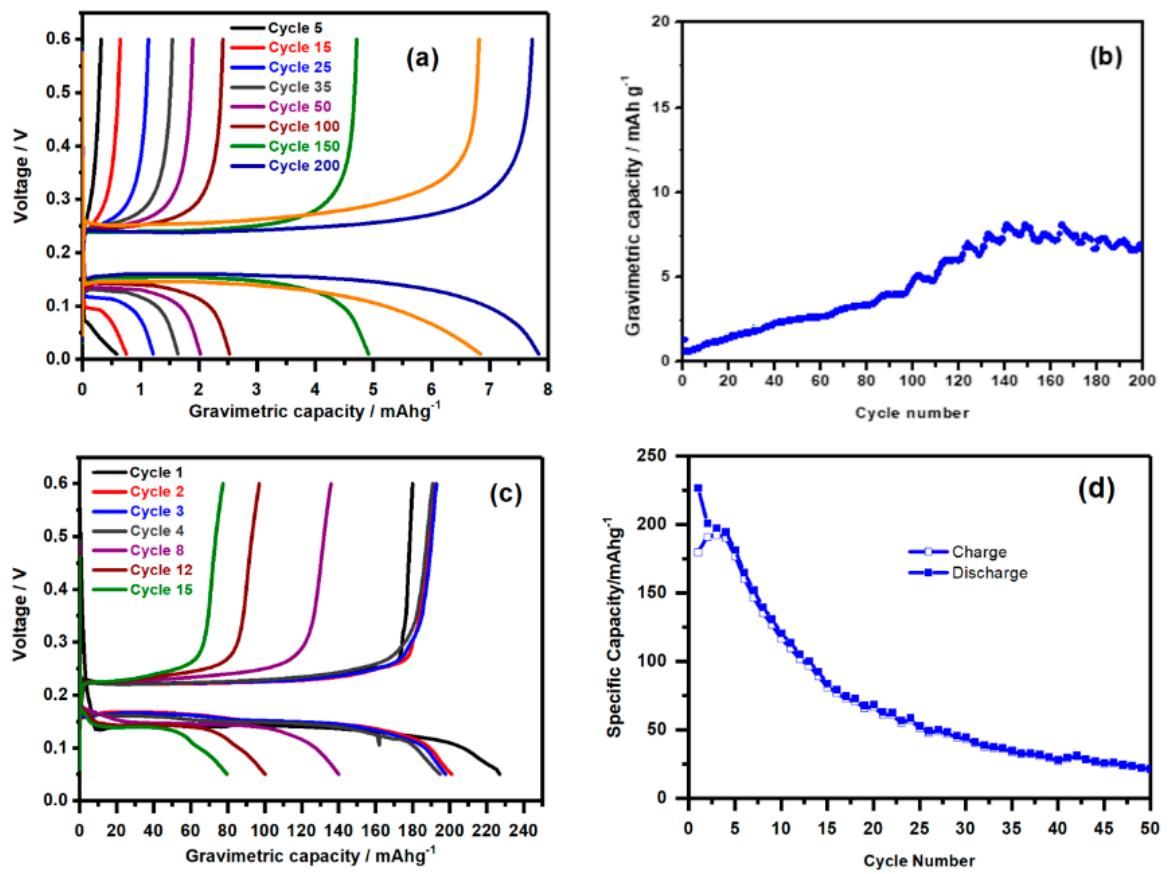

Figure 3. (a) Galvanostatic charge-discharge plots and (b) cycling performance at at $10 \mathrm{~mA} / \mathrm{g}$ $(\mathrm{C} / 20)$ current density of microparticulate $\beta$-Sn in $\mathrm{Mg}$ half-cell, using $0.5 \mathrm{M} \mathrm{PhMgCl}$ in $\mathrm{THF}$ as electrolyte. (c) Galvanostatic charge-discharge plots and (d) cycling performance at $10 \mathrm{~mA} / \mathrm{g}(\mathrm{C} / 20)$ of nanoparticulate-Sn in in $\mathrm{Mg}$ half-cell using $0.5 \mathrm{M} \mathrm{EtMgCl}$ in THF as electrolyte.

Table 2. IS, QS, LW, \% contribution and attribution of the signals appearing in the ${ }^{119} \mathrm{Sn}$ Mössbauer spectra of commercial micro- and nano-Sn, mechanochemically produced $\mathrm{Mg}_{2} \mathrm{Sn}$ and discharged/recharged electrodes. * Recoilless fractions, $f=0.05$ ( $\mathrm{Sn}$ and $\left.\mathrm{d}-\mathrm{Mg}_{\delta} \mathrm{Sn}\right), 0.35(\mathrm{SnO})$, $0.60\left(\mathrm{SnO}_{2}\right)$, and $0.3\left(\mathrm{c}-\mathrm{Mg}_{2} \mathrm{Sn}\right)$ [28,29]. Copyright Elsevier, 2000, 1966. These values were used to convert spectral contributions (\%) into semiquantitative composition $\left(\%_{\text {corr }}\right)$.

\begin{tabular}{|c|c|c|c|c|c|c|}
\hline Sample (Nominal) & $\mathrm{IS} / \mathrm{mms}^{-1}$ & $\mathrm{QS} / \mathrm{mms}^{-1}$ & $\mathrm{LW} / \mathrm{mms}^{-1}$ & $\%$ & $\%_{\text {corr }} *$ & Attribution \\
\hline \multirow[t]{3}{*}{ (a) nano-Sn } & $2.579_{8}$ & - & $1.41_{9}$ & 33 & 76 & $\beta-S n$ \\
\hline & $2.75_{3}$ & $1.52_{5}$ & $1.12_{2}$ & 25 & 2 & $\mathrm{SnO}$ \\
\hline & $0.026_{7}$ & $1.58_{1}$ & $1.16_{5}$ & 42 & 13 & $\mathrm{SnO}_{2}$ \\
\hline \multirow{3}{*}{$\begin{array}{l}\text { (b) nano- } \mathrm{Mg}_{1.3} \mathrm{Sn} \\
\text { discharged }\end{array}$} & $1.87_{1}$ & - & $0.88_{4}$ & 40 & 50 & $\mathrm{c}-\mathrm{Mg}_{2} \mathrm{Sn}$ \\
\hline & $2.85_{6}$ & $0.90_{6}$ & $1.0_{1}$ & 27 & 29 & $\mathrm{SnO}$ \\
\hline & $0.05_{2}$ & $0.53_{3}$ & $0.83_{6}$ & 33 & 21 & $\mathrm{SnO}_{2}$ \\
\hline (c) thermal-MgSn & $2.67_{2}$ & - & $1.04_{3}$ & 14 & 60 & $\mathrm{~d}-\mathrm{Mg}_{\delta} \mathrm{Sn}$ \\
\hline \multirow{3}{*}{ discharged + charged } & $1.90_{3}$ & - & $1.04_{4}$ & 9 & 7 & $\mathrm{c}-\mathrm{Mg}_{2} \mathrm{Sn}$ \\
\hline & $2.81_{2}$ & $1.22_{3}$ & $1.04_{1}$ & 23 & 14 & $\mathrm{SnO}$ \\
\hline & $0.05_{1}$ & $0.55_{1}$ & $0.94_{2}$ & 54 & 19 & $\mathrm{SnO}_{2}$ \\
\hline (d) micro- $\mathrm{Mg}_{0.4} \mathrm{Sn}$ & $2.70_{8}$ & - & $0.87_{4}$ & 15 & 60 & $\mathrm{~d}-\mathrm{Mg}_{\delta} \mathrm{Sn}$ \\
\hline discharged + fully & $2.71_{2}$ & $1.57_{3}$ & $0.87_{7}$ & 26 & 17 & $\mathrm{SnO}$ \\
\hline charged & $0.05_{1}$ & $0.54_{2}$ & $0.96_{3}$ & 61 & 23 & $\mathrm{SnO}_{2}$ \\
\hline
\end{tabular}

To improve the electrochemical performance, a nanodispersed commercial sample (nano-Sn) was also assessed. ${ }^{119} \mathrm{Sn}$ MS data were also recorded. This spectrum was deconvoluted in several components attributed to $\beta-\mathrm{Sn}$, a quadrupole split signal of $\mathrm{SnO}\left(\mathrm{IS}=2.65 \mathrm{~mm} \mathrm{~s}^{-1}\right)$, and $\mathrm{SnO}_{2} \mathrm{with}$ cassiterite structure with IS ca. $0.0 \mathrm{~mm} \mathrm{~s}^{-1}$ (Figure $4 \mathrm{a}$ and Table 2) [28]. The high intensity of the signals attributed to tin oxides, as compared with that of metallic tin is a consequence of the significantly lower $f$ value for the latter. The necessary corrections lead to an atomic percentage of $76 \% \beta-S n$. The XRD pattern shows reflections of $\beta$-Sn and some additional low intensity lines that could be ascribable 
to SnO (Figure 5) to support this conclusion. The presence of the oxides may involve the surface oxidation of the tin nanoparticles. This process is particularly visible in nanoparticulate materials due to their high surface-to-volume ratio. However, its presence could provide passivation of the electrode material that could prevent undesirable surface reactions with the electrolyte during the cycling or contribute to the total capacity if the oxides are electroactive. Figure 6 shows the FESEM images of micro and nano-Sn. In contrast to the ca. $100 \mu \mathrm{m}$ particles of crystalline tin, nano-Sn shows particles around $100 \mathrm{~nm}$. Also, the EDX spectra showed an average Sn/O atomic ratio of 1.16, and the composition mapping showed a uniform distribution of oxygen in the surface of the particles. With this in mind, we decided to use the nano-Sn sample without further chemical treatments for the electrochemical experiments.

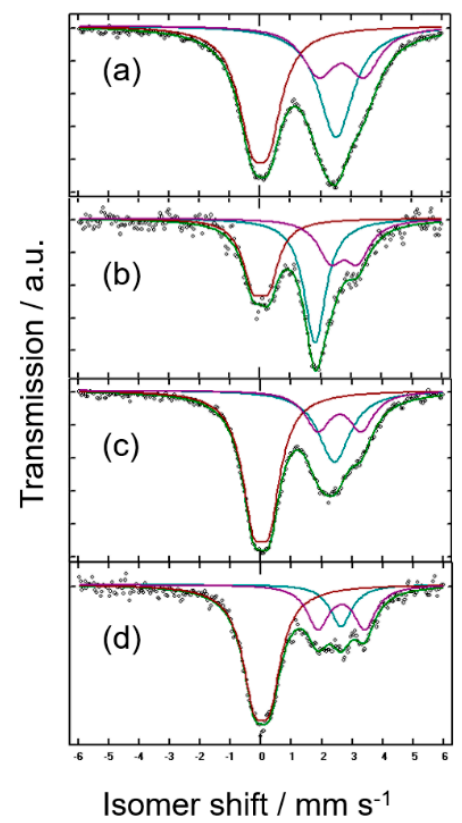

Figure 4. ${ }^{119}$ Sn Mössbauer spectra of (a) Commercial nano-Sn, and (b) discharged nano-Sn electrodes in Mg half-cell to a $\mathrm{Mg}_{1.3} \mathrm{Sn}$ nominal composition. (c) Discharged-charged nano-Sn electrodes in $\mathrm{Mg}$ half-cell to a $\mathrm{Mg}_{0.4} \mathrm{Sn}$ nominal composition. (d) Discharged-fully charged nano-Sn electrodes in Mg half-cell.

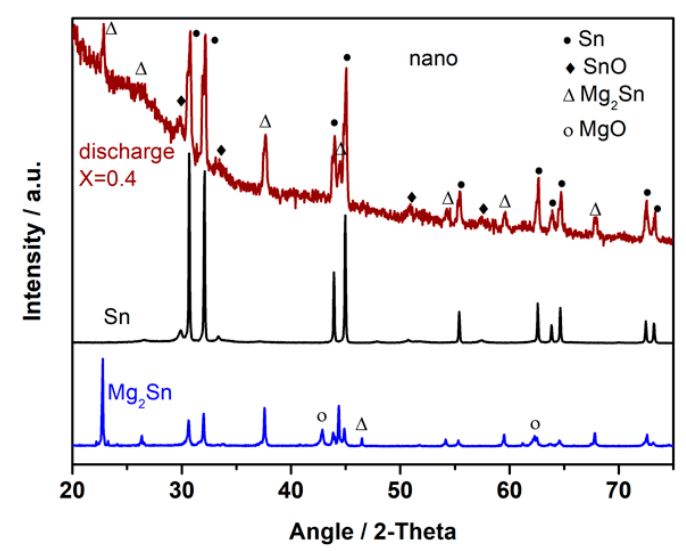

Figure 5. XRD pattern of commercial nano-Sn, and discharged nano-Sn electrode in $\mathrm{Mg}$ half-cell at $\mathrm{Mg}_{x} \mathrm{Sn}$ nominal compositions with $x=0.4$ and $x=2.0$.

Figure $3 \mathrm{c}$, d shows the galvanostatic cycling experiments of $\mathrm{Mg} /$ nano-Sn half-cells. The initial capacity $\left(225 \mathrm{~mA} \mathrm{~h}^{-1}\right)$ is higher and cell polarization is lower than that of micro-Sn cell, 
preserving well-defined plateaus. However, capacity fades for prolonged cycling, as that of micro-Sn, probably because of the poor response of the $\mathrm{Mg}$ metal electrode in the used electrolytes. However, nanodispersion is expected to be a suitable strategy to improve the initial capacity of full Mg-ion batteries, such as the proof of concept discussed below. The average discharge and charge voltages are $0.1 \mathrm{~V}$ and $0.25 \mathrm{~V}$, respectively. The limited cell polarization and low charge potential suggest that a $\mathrm{Sn} / 0.5 \mathrm{M} \mathrm{PhMgCl}(\mathrm{THF}) / \mathrm{MgMn}_{2} \mathrm{O}_{4}$ full cell (ca. $2.0 \mathrm{~V}$ ) would provide a suitable energy density.

Figure $4 \mathrm{~b}$ shows ${ }^{119} \mathrm{Sn}$ MS data for nano-Sn electrodes after discharge to a nominal $\mathrm{Mg}_{1.3} \mathrm{Sn}$ composition. The fitting parameters in Table 2 reveal the expected formation of c- $\mathrm{Mg}_{2} \mathrm{Sn}$; however, the tin oxides initially present in the samples are still present, thus offering a sufficient coating of the tin nanoparticles to be preserved during the alloying-dealloying process and stabilize the electrode structure upon cycling. The XRD pattern for $x=0.4$ in Figure 5 is also in agreement with the MS data. The good reversibility of the process is exemplified by the ${ }^{119} \mathrm{Sn}$ MS data for nano-Sn electrodes after recharge to a nominal $\mathrm{Mg}_{0.4} \mathrm{Sn}$ composition (Figure $4 \mathrm{c}, \mathrm{d}$ and Table 2). Although the oxide lines were always present, it can be highlighted that the initial $\mathrm{SnO}_{2} / \mathrm{SnO}$ ratio in nano-Sn decreases during the discharge and increases again during charge. The $\mathrm{SnO}_{2} / \mathrm{SnO}$ pair can be then considered electroactive, as shown in other systems [28]. Not only does this prevent undesirable surface reactions but it also contributes to the overall capacity.
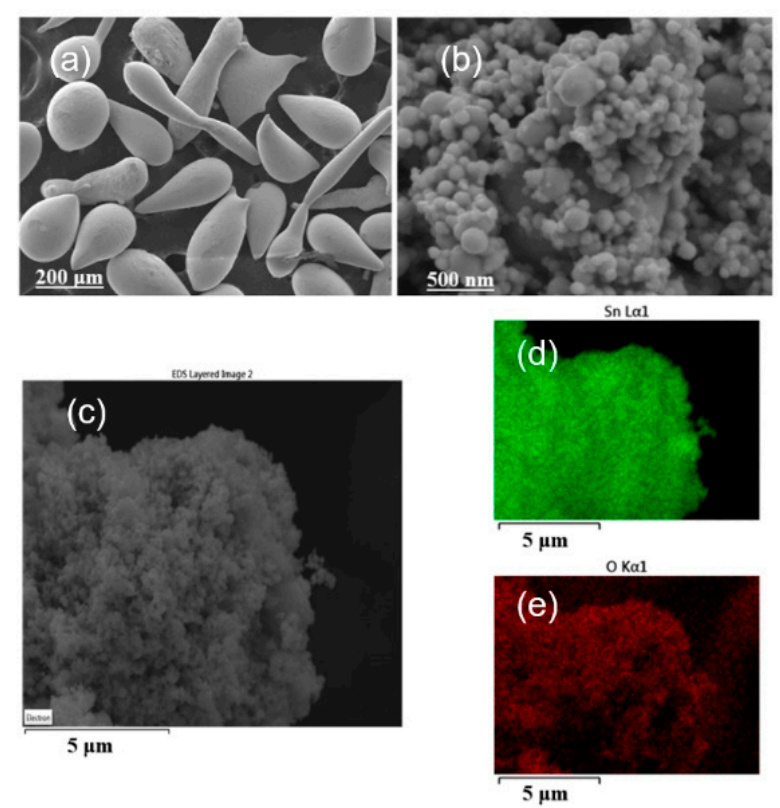

Figure 6. FESEM (Field-Emission Scanning Electron Microscope) images of (a) micro-Sn, and (b,c) nano-Sn. EDX composition mapping of nano-Sn: (d) tin and (e) oxygen.

A better perspective of the possible use of these materials as anodes in Mg-ion batteries can be given by trying their electrochemical behavior in full cells. For this purpose, the cycling properties of the nano-Sn $/ \mathrm{MgMn}_{2} \mathrm{O}_{4}$ full cells were tested with different electrolyte solutions. The expected overall reaction can be written as:

$$
2 \mathrm{MgMn}_{2} \mathrm{O}_{4}+x \text { nano-Sn } \rightleftharpoons 2 \mathrm{Mg}_{1-x} \mathrm{Mn}_{2} \mathrm{O}_{4}+x \mathrm{Mg}_{2} \mathrm{Sn}
$$

Due to the incompatibility of the organometallic electrolytes versus $\mathrm{MgMn}_{2} \mathrm{O}_{4}$ [16], and perchlorate electrolytes in acetonitrile versus $\mathrm{Mg}$ metal, we will avoid the use of $\mathrm{Mg}$ metal in full cells. Then, the changes in the voltage of nano-Sn $/ \mathrm{MgMn}_{2} \mathrm{O}_{4}$ full cell were monitored by using two electrode cells and $\mathrm{Mg}\left(\mathrm{ClO}_{4}\right)_{2}$ in $\mathrm{AN}$ as the electrolyte. Several mass ratios $\mathrm{m}_{+} / \mathrm{m}$ - were examined. 
Figure 7 shows the best response observed that corresponds to a spinel mass excess $\left(\mathrm{m}_{+} / \mathrm{m}_{-}=4.0\right)$ that could provide enough magnesium extraction from the cathode during charge to complete Equation (2) in the anode, even if $x=1.0$. The capacities were thus calculated by using the anode mass. The full Mg-ion cell showed the typical S-shaped voltage profile with an average discharge potential close

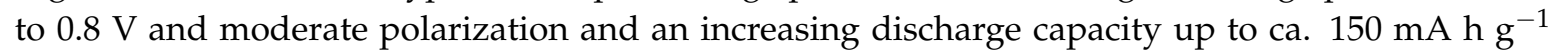
(Figure 7). This trend is related with the conditioning behavior of the anode that was discussed in the light of Figure 3. An energy density of up to ca. $120 \mathrm{~W} \mathrm{~h} \mathrm{~kg}^{-1}$ can be estimated considering the mass of the anode.

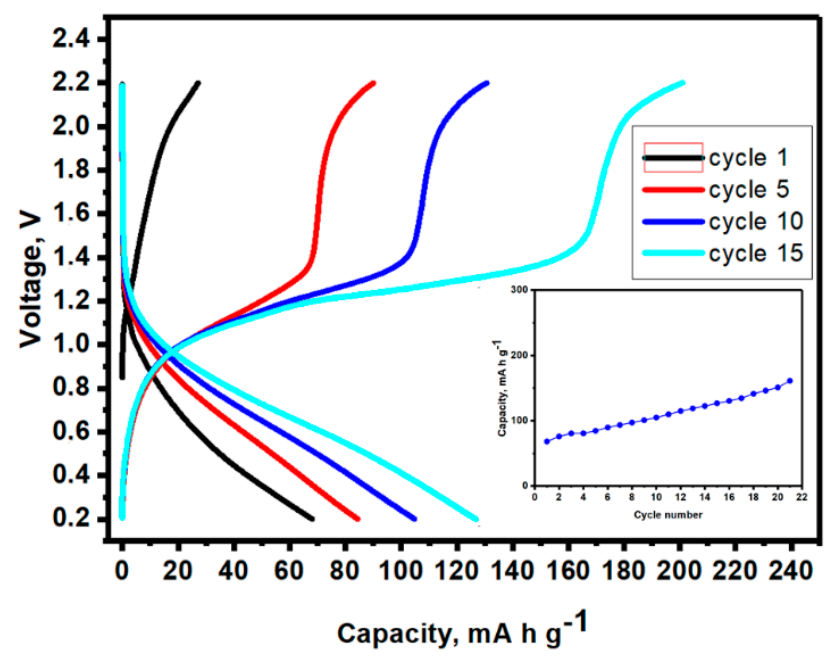

Figure 7. Galvanostatic charge-discharge plot at $20 \mathrm{~mA} \mathrm{~g}^{-1}$ of a nano-Sn/ $\mathrm{MgMn}_{2} \mathrm{O}_{4}$ full cell, using $0.5 \mathrm{M}$ $\mathrm{Mg}\left(\mathrm{ClO}_{4}\right)_{2}$ in AN electrolyte and $\mathrm{m}_{+} / \mathrm{m}_{-}=4: 1$. Inset: Capacity vs. cycle number.

\section{Conclusions}

The alternative intermetallic anode $\mathrm{Mg}_{2} \mathrm{Sn} / \mathrm{Sn}$ for $\mathrm{Mg}$-ion batteries is evaluated in $\mathrm{Mg}$ half cells with the valuable help of ${ }^{119} \mathrm{Sn}$ Mössbauer spectroscopy. This technique suggests the electrochemical alloying-dealloying properties by a complex mechanism involving amorphous intermetallic phases with an electric field gradient in the environment of tin atoms. The small but significant quadrupolar splitting revealed by the fitting of the spectra of the signal ascribable to the tin-rich phase is indicative of an electric field gradient environment of tin atoms. This is probably due to the presence of lower symmetry environments than in $\mathrm{c}-\mathrm{Mg}_{2} \mathrm{Sn}$, because of an incomplete magnesiation. Thus, the coordination polyhedra of tin in c- $\mathrm{Mg}_{2} \mathrm{Sn}\left(\mathrm{CaF}_{2}\right.$-related structure) are $\mathrm{SnMg} 8$ cubes. For a no-stoichiometric intermediate, $\mathrm{SnMg}_{8-x}$ polyhedral are less regular and cause the splitting of the nuclear spin levels of the quadrupolar ${ }^{119} \mathrm{Sn}$ nuclei. Nanoparticulate tin was also examined. Tin nanoparticles are surrounded by a $\mathrm{SnO} / \mathrm{SnO}_{2}$ film due to surface oxidation and are partially reduced during cycling. Their lower diffusion lengths for magnesium improve the initial capacity as compared to tin microparticles, although capacity fading is observed, probably because of the magnesium metal electrodes. Thus, the use of full $\mathrm{Mg}$-ion cells has been tested as a proof of concept. The spinel-related solid, $\mathrm{MgMn}_{2} \mathrm{O}_{4}$, which is known to deintercalate magnesium by chemical and electrochemical means in both aqueous and non-aqueous electrolytes, was found to be compatible with $\mathrm{Mg}_{2} \mathrm{Sn}$ anodes. Cycling properties of the full $\mathrm{Mg}$-ion cells provided voltages around $0.8 \mathrm{~V}$. Capacity values and their retention during cycling were good for the $\mathrm{Mg}\left(\mathrm{ClO}_{4}\right)_{2}-\mathrm{AN}$ electrolyte. In this case, a reversible discharge capacity of ca. $25 \mathrm{~mA} \mathrm{~h} \mathrm{~g}^{-1}$ and maximum energy density of ca. $120 \mathrm{~W} \mathrm{~h} \mathrm{~kg}^{-1}$ were observed. and R.A.; Investigation, F.N., M.C., C.P.-V., P.L. and G.F.O.; Project administration, G.F.O. and J.L.T.; Software, 
C.P.-V.; Supervision, P.L.; Writing, original draft, R.A., G.F.O. and J.L.T.; Writing, review \& editing, P.L., G.F.O. and J.L.T.

Funding: This research was funded by Ministerio de Ciencia, Innovación y Universidades grant numbers MAT2014-56470-R, and MAT2017-84002-C2-1-R), and ERDF funds and Junta de Andalucía grant number FQM288.

Acknowledgments: We also thank the Fine Chemistry Institute (IUIQFN).

Conflicts of Interest: The authors declare no conflict of interest. The funders had no role in the design of the study; in the collection, analyses, or interpretation of data; in the writing of the manuscript, and in the decision to publish the results.

\section{References}

1. Gerst, M.D.; Graedel, T.E. In-Use Stocks of Metals: Status and Implications. Environ. Sci. Technol. 2008, 42, 7038-7044. [CrossRef] [PubMed]

2. Tarascon, J.M. Is lithium the new gold? Nat. Chem. 2010, 2, 510. [CrossRef] [PubMed]

3. Wadia, C.; Albertus, P.; Srinivasan, V. Resource constraints on the battery energy storage potential for grid and transportation applications. J. Power Sources 2011, 196, 1593-1598. [CrossRef]

4. Speirs, J.; Contestabile, M.; Houari, Y.; Gross, R. The future of lithium availability for electric vehicle batteries. Renew. Sustain. Energy Rev. 2014, 35, 183-193. [CrossRef]

5. Lyon, R.E.; Walters, R.N. Energetics of lithium ion battery failure. J. Hazard. Mater. 2016, 318, $164-172$. [CrossRef] [PubMed]

6. Novák, P.; Imhof, R.; Haas, O. Magnesium insertion electrodes for rechargeable nonaqueous batteries-A competitive alternative to lithium? Electrochim. Acta 1999, 45, 351-367. [CrossRef]

7. Aurbach, D.; Lu, Z.; Schechter, A.; Gofer, Y.; Gizbar, H.; Turgeman, R.; Cohen, Y.; Moshkovich, M.; Levi, E. Prototype systems for rechargeable magnesium batteries. Nature 2000, 407, 724-727. [CrossRef] [PubMed]

8. Saha, P.; Datta, M.K.; Velikokhatnyi, O.I.; Manivannan, A.; Alman, D.; Kumta, P.N. Rechargeable magnesium battery: Current status and key challenges for the future. Prog. Mater. Sci. 2014, 66, 1-86. [CrossRef]

9. Zhao-Karger, Z.; Zhao, X.Y.; Wang, D.; Thomas, D.; Behm, R.J.; Fichtner, M. Performance Improvement of Magnesium Sulfur Batteries with Modified Non-Nucleophilic Electrolytes. Adv. Energy Mater. 2015, 5, 1401155. [CrossRef]

10. Song, J.; Sahadeo, E.; Noked, M.; Lee, S.B. Mapping the Challenges of Magnesium Battery. J. Phys. Chem. Lett. 2016, 7, 1736-1749. [CrossRef] [PubMed]

11. Jia, X.; Wang, C.; Ranganathan, V.; Napier, B.; Yu, C.; Chao, Y.; Forsyth, M.; Omenetto, F.G.; MacFarlane, D.R.; Wallace, G.G. A Biodegradable Thin-Film Magnesium Primary Battery Using Silk Fibroin-Ionic Liquid Polymer Electrolyte. ACS Energy Lett. 2017, 2, 831-836. [CrossRef]

12. Muldoon, J.; Bucur, C.B.; Gregory, T. Quest for Nonaqueous Multivalent Secondary Batteries: Magnesium and Beyond. Chem. Rev. 2014, 114, 11683-11720. [CrossRef] [PubMed]

13. Canepa, P.; Gautam, G.S.; Hannah, D.C.; Malik, R.; Liu, M.; Gallagher, K.G.; Persson, K.A.; Ceder, G. Odyssey of Multivalent Cathode Materials: Open Questions and Future Challenges. Chem. Rev. 2017, 117, 4287-4341. [CrossRef] [PubMed]

14. Okamoto, S.; Ichitsubo, T.; Kawaguchi, T.; Kumagai, Y.; Oba, F.; Yagi, S.; Shimokawa, K.; Goto, N.; Doi, T.; Matsubara, E. Intercalation and Push-Out Process with Spinel-to-Rocksalt Transition on Mg Insertion into Spinel Oxides in Magnesium Batteries. Adv. Sci. 2015, 2, 1500072. [CrossRef] [PubMed]

15. Knight, J.C.; Therese, S.; Manthiram, A. On the Utility of Spinel Oxide Hosts for Magnesium-Ion Batteries. ACS Appl. Mater. Interfaces 2015, 7, 22953-22961. [CrossRef] [PubMed]

16. Cabello, M.; Alcántara, R.; Nacimiento, F.; Ortiz, G.; Lavela, P.; Tirado, J.L. Electrochemical and chemical insertion/deinsertion of magnesium in spinel-type $\mathrm{MgMn}_{2} \mathrm{O}_{4}$ and lambda- $\mathrm{MnO}_{2}$ for both aqueous and non-aqueous magnesium-ion batteries. CrystEngComm 2015, 17, 8728-8735. [CrossRef]

17. Singh, N.; Arthur, T.S.; Ling, C.; Matsui, M.; Mizuno, F. A high energy-density tin anode for rechargeable magnesium-ion batteries. Chem. Commun. 2013, 49, 149-151. [CrossRef] [PubMed]

18. Courtney, I.A.; Dunlap, R.A.; Dahn, J.R. In-situ ${ }^{119}$ Sn Mössbauer effect studies of the reaction of lithium with $\mathrm{SnO}$ and SnO:0.25 $\mathrm{B}_{2} \mathrm{O}_{3}: 0.25 \mathrm{P}_{2} \mathrm{O}_{5}$ glass. Electrochim. Acta 1999, 45, 51-58. [CrossRef] 
19. Fernández-Madrigal, F.J.; Lavela, P.; Pérez-Vicente, C.; Tirado, J.L.; Jumas, J.C.; Olivier-Fourcade, J. X-ray Diffraction, 7Li MAS NMR Spectroscopy, and 119Sn Mössbauer Spectroscopy Study of SnSb-Based Electrode Materials. Chem. Mater. 2002, 14, 2962-2968. [CrossRef]

20. Alcántara, R.; Ortiz, G.F.; Lavela, P.; Tirado, J.L. Electrochemical and ${ }^{119}$ Sn Mössbauer studies of the reaction of $\mathrm{Co}_{2} \mathrm{SnO}_{4}$ with lithium. Electrochem. Commun. 2006, 8, 731-736.

21. Aldon, L.; Ionica, C.M.; Lippens, P.E.; Larcher, D.; Tarascon, J.M.; Olivier-Fourcade, J.; Jumas, J.C. In situ ${ }^{119} \mathrm{Sn}$ Mössbauer spectroscopy used to study lithium insertion in c- $\mathrm{Mg}_{2} \mathrm{Sn}$. Hyperfine Interact. 2006, 167, 729-732. [CrossRef]

22. Alcántara, R.; Rodríguez, I.; Tirado, J.L. Structural and Electrochemical Properties of Micro-and Nano-Crystalline CoSn Electrode Materials. ChemPhysChem 2008, 9, 1171-1177. [CrossRef] [PubMed]

23. Gogotsi, Y.; Penner, R.M. Energy Storage in Nanomaterials - Capacitive, Pseudocapacitive, or Battery-like? ACS Nano 2018, 12, 2081-2083. [CrossRef] [PubMed]

24. Liu, Z.; Lee, J.; Xiang, G.; Glass, H.F.J.; Keyzer, E.N.; Dutton, S.E.; Grey, C.P. Insights into the Electrochemical Performances of Bi Anodes for Mg-Ion Batteries Using ${ }^{25} \mathrm{Mg}$ Solid State NMR Spectroscopy. Chem. Commun. 2018, 4, 743-746. [CrossRef] [PubMed]

25. Kapitanov, E.V.; Pakovl, E.K. Mössbauer Study of Phase Transitions (I) The Phase Transition of $\mathrm{Mg}_{2} \mathrm{Sn}$. Phys. State Solids A 1979, 53, 473-480. [CrossRef]

26. Sirkin, H.; Mingolo, E.; Nassif, N.; Arcondo, B. Increase of the glass-forming composition range of Mg-based binary alloys by addition of tin. J. Non-Cryst. Solids 1987, 93, 323-330. [CrossRef]

27. Fries, S.G.; Lukas, H.L. Optimisation of the Mg-Sn System. J. Chim. Phys. 1993, 90, 181-187. [CrossRef]

28. Chouvin, J.; Olivier-Fourcade, J.; Jumas, J.C.; Simon, B.; Biensan, P.; Fernández Madrigal, F.J.; Tirado, J.L.; Pérez-Vicente, C. SnO reduction in lithium cells: Study by X-ray absorption, ${ }^{119} \mathrm{Sn}$ Mössbauer spectroscopy and X-ray diffraction. J. Electroanal. Chem. 2000, 494, 136-146. [CrossRef]

29. Stockler, H.A.; Sano, H. Mössbauer recoilless fraction in tin compounds. Nucl. Instrum. Meth. 1966, 44, 103-108. [CrossRef] 